\title{
MAPEAMENTO DA CAPACIDADE DE USO DAS TERRAS NA BACIA HIDROGRÁFICA DO PARANÁ 3: CONTRIBUIÇÕES PARA O PLANEJAMENTO RURAL E AMBIENTAL
}

\author{
Anderson Sandro da Rocha \\ Universidade Tecnológica Federal do Paraná \\ Professor do Departamento de Ciências Ambientais, Santa Helana, PR, Brasil \\ andersonrocha@utfpr.edu.br \\ Maria Teresa de Nóbrega \\ Universidade Estadual de Maringá \\ Professora do Programa de Pós Graduação em Geografia, Maringá, PR, Brasil \\ mtnobrega@uol.com.br
}

José Edézio da Cunha Universidade Estadual do Oeste do Paraná Professor do Programa de Pós Graduação em Geografia Marechal Cândido Rondon, PR, Brasil edeziocunha@hotmail.com

Maicol Rafael Bade Doutorando da Pós Graduação em Geografia, Maringá, PR, Brasil maicolbade@yahoo.com.br

\begin{abstract}
RESUMO
O mapeamento das terras no sistema de capacidade de uso tem permitido identificar as melhores práticas de preservação e conservação dos solos em escalas locais, regionais e particularmente nas unidades das bacias hidrográficas. Esses levantamentos têm contribuído com informações úteis para a definição das diretrizes e ações a serem implementadas no espaço físico-territorial, servindo de base para o planejamento rural e ambiental. Nesse sentido, o presente trabalho tem como objetivo a identificação e o mapeamento da capacidade de uso das terras na bacia hidrográfica do Paraná 3 , região Oeste do Paraná. Na primeira etapa foram desenvolvidas cartas temáticas (pedológicas, geológicas, topográficas e de uso e cobertura da terra). Em seguida foi realizado o enquadramento das classes e subclasses de capacidade evolvendo dez diferentes ordens de solos existentes na bacia. O levantamento possibilitou identificar três subclasses adaptadas aos cultivos agrícolas e pecuários (Ile - IIIs,e - IIle), com necessidade de práticas mais intensivas ou mesmos complexas de conservação do solo; duas subclasses com uso limitado para pastagens, florestas cultivadas ou nativas (VIs,e - VIs,a) e uma subclasse com restrição ao uso agropecuário (VIIIs,a), indicada somente para o abrigo e proteção da fauna e da flora silvestre.
\end{abstract}

Palavras-chave: Cobertura pedológica. Conservação do solo. Sistemas agrícolas e pecuários.

\section{MAPPING OF CAPACITY OF LAND USE IN THE PARANÁ 3 WATERSHED: CONTRIBUTIONS TO RURAL AND ENVIRONMENTAL PLANNING}

\begin{abstract}
The mapping of land in the system of use capacity has allowed to identify the best practices of soil preservation and conservation in local, regional scales and particularly in the units of the hydrological basins. These surveys have contributed with useful information for the definition of guidelines and actions to be implemented in the physical-territorial space, serving as the basis for rural and environmental planning. In this sense, the present work has the objective of identifying and mapping the land use capacity in the Paraná 3 watershad, western region of Paraná. In the first stage, thematic maps were developed (pedological, geological, topographical and of the use and coverage of the land). Next, the classification of the classes and subclasses of capacity was carried out evolving ten different orders of soils existing in the basin. The survey made it possible to identify three subclasses adapted to agricultural and livestock (Ile - IIIs, and - IIle), with the need for more intensive or even complex soil conservation practices; two subclasses with limited use for pastures,
\end{abstract}


cultivated or native forests (VIs, and - VIs, a) and a subclass with restriction to agricultural use (VIIIs, a), indicated only for the shelter and protection of wild fauna and flora.

Keywords: Pedological cover. Soil Conservation. Agricultural and livestock systems.

\section{INTRODUÇÃO}

O retorno da gênese e evolução de processos erosivos, laminares e lineares, nos solos agricultáveis do estado do Paraná tem gerado perdas na produção e na produtividade agropecuária. $O$ que significa dizer que tem sido necessário um conjunto de programas e propostas que visem o desenvolvimento de ações estruturais que retomem o processo de conservação do solo e da água no Estado (SEAB, 2017).

Nesse contexto, o planejamento racional do uso da terra, apresenta-se como ferramenta essencial para a manutenção da sustentabilidade dos solos, produção agrícola e proteção da biodiversidade, uma vez que, orienta o desenvolvimento de atividades adequadas às potencialidades e limitações do meio físico (FLAUZINO et al., 2016).

Um dos primeiros passos para a recuperação das áreas degradadas e consequentemente da preservação do ambiente é a realização do planejamento de uso e manejo do solo em bases conservacionistas. Tais procedimentos devem ser iniciados pelo diagnóstico dos recursos naturais da área, primeiramente pelo reconhecimento dos atributos dos solos que comandam a sua capacidade de uso (SANTOS et al., 2012).

Nesse sentido, insere-se o mapeamento das terras no sistema de capacidade de uso proposto por Lepsch et al. (1991). Com esse sistema são caracterizados grupos, classes e subclasses que visam a identificação das melhores práticas de uso e/ou preservação dos solos. Os grupos constituem o primeiro nível de análise e estabelecem três modelos de utilização dos solos em ordem decrescente, determinados pelas letras A, B, C. O grupo A não apresenta nenhum tipo de restrição ao uso agrícola ou pecuário, contemplando terras passíveis de utilização com culturas anuais, perenes, pastagens e/ou reflorestamento. O grupo B engloba terras impróprias para cultivos intensivos, mas ainda adaptadas para pastagens e/ou reflorestamento e vida silvestre. Enquanto o grupo $\mathrm{C}$ compreende terras não adequadas para cultivos anuais, perenes, pastagens ou reflorestamento, porém apropriadas para proteção da flora e fauna silvestre, recreação ou armazenamento de água (LEPSCH et al., 2015).

$\mathrm{Na}$ avaliação do sistema de capacidade, cada grupo contém diferentes classes: o grupo A apresenta as classes I, II, III e IV; o grupo B as classes V, VI e VII; o grupo C a classe VIII. Essas classes apresentam, segundo Lepsch et al. (2015), os níveis de conservação que devem ser empregados em cada parcela de solo.

Nesse modelo, à determinação das classes de capacidade de uso podem ainda ser associadas às subclasses, nas quais são definidos os fatores limitantes, como os referentes ao relevo, que evidencia o risco a erosão (como por exemplo, áreas de declives acentuados), ao solo (como solos de baixa profundidade e textura arenosa), as limitações hídricas (relativas ao excesso de água) ou, ainda, climáticas (áreas de secas prolongadas, ou riscos constantes de geadas). Embora um conjunto de fatores pedológicos, topográficos, hídricos e climáticos sejam considerados na determinação da capacidade de uso, Melo e Guerra (2013) destacam que, em grande parte dos estudos, o solo é o principal fator natural condicionador da capacidade de uso da terra.

A partir dessas indicações, trabalhos regionais (MAGALHÃES e CUNHA, 2006; ROCHA et al., 2016), voltados a avaliação dos sistemas pedológicos em associação com a capacidade de uso dos sistemas agrícolas, destacam a importância do conhecimento dos solos e suas relações com o relevo como indispensáveis para a análise ambiental. Desse modo, a identificação de diferentes conjuntos pedológicos em associação com as unidades geomorfológicas podem facilitar a execução de mapeamentos que possibilitem a execução de propostas para a otimização do uso do solo e aplicação de práticas de manejo que respeitem as suas limitações.

Com base nessas concepções, pesquisas mais recentes sobre o tema, como as de Nanni et al. (2005), Silva et al. (2010) e Santos et al. (2012), vem empregando técnicas de geoprocessamento

$\begin{array}{llllll}\text { Caminhos de Geografia } & \text { Uberlândia - MG } & \text { v. 19, n. } 68 & \text { Dez/2018 } & \text { p. 266-285 } & \text { Página } 267\end{array}$


com o intuito de gerar cartas temáticas, voltadas a aptidão agrícola e capacidade de uso dos solos. Esses trabalhos adotando a bacia hidrográfica como unidade de análise espacial, tem como princípio a possibilidade de demonstrar a fragilidade dos elementos físicos em relação às práticas antrópicas em documentos cartográficos que trazem informações úteis ao planejamento ambiental e territorial. Segundo os autores, a utilização dos Sistemas de Informações Geográficas (SIGs), colabora tanto na classificação individual das vulnerabilidades e susceptibilidades dos elementos naturais e antrópicos da bacia, quanto na análise integrada, uma vez que além de propiciarem rapidez de processamento, ampliam a capacidade de modelagem e decisão.

A partir dessas premissas, o presente trabalho teve o objetivo de identificar e mapear a capacidade de uso das terras na Bacia Hidrográfica do Paraná (BP3), visando, sobretudo, contribuir com a indicação de práticas de conservação adequadas à realidade geomorfopedológica desta unidade de paisagem. Dessa forma são apresentadas informações sobre a distribuição espacial da cobertura pedológica e do uso da terra, bem como cartas temáticas e de capacidade de uso das terras. Essas cartas, podem trazer informações úteis para a definição das diretrizes e ações a serem implementadas no espaço físico-territorial, servindo de base para o planejamento rural e ambiental.

\section{ÁREA DE ESTUDO}

A área de pesquisa corresponde à BP3, uma das doze unidades hidrográficas do Estado do Paraná, delimitadas pela Secretaria do Meio Ambiente e Recursos Hídricos - SEMA (2013), com o objetivo de gestão e planejamento ambiental. Está localizada na mesorregião Oeste do Estado do Paraná, entre as latitudes $24^{\circ} 01^{\prime} \mathrm{S}$ e $25^{\circ} 35^{\prime} \mathrm{S}$ e longitudes $53^{\circ} 26^{\prime} \mathrm{W}$ e $54^{\circ} 37^{\prime} \mathrm{W}$ e abrange uma área de aproximadamente $8.000 \mathrm{~km}^{2}$ que abriga, de modo parcial ou total, os territórios de 28 municípios (Figura 1).

Figura 1: Localização da Bacia Hidrográfica do Paraná 3, região Oeste do Paraná.

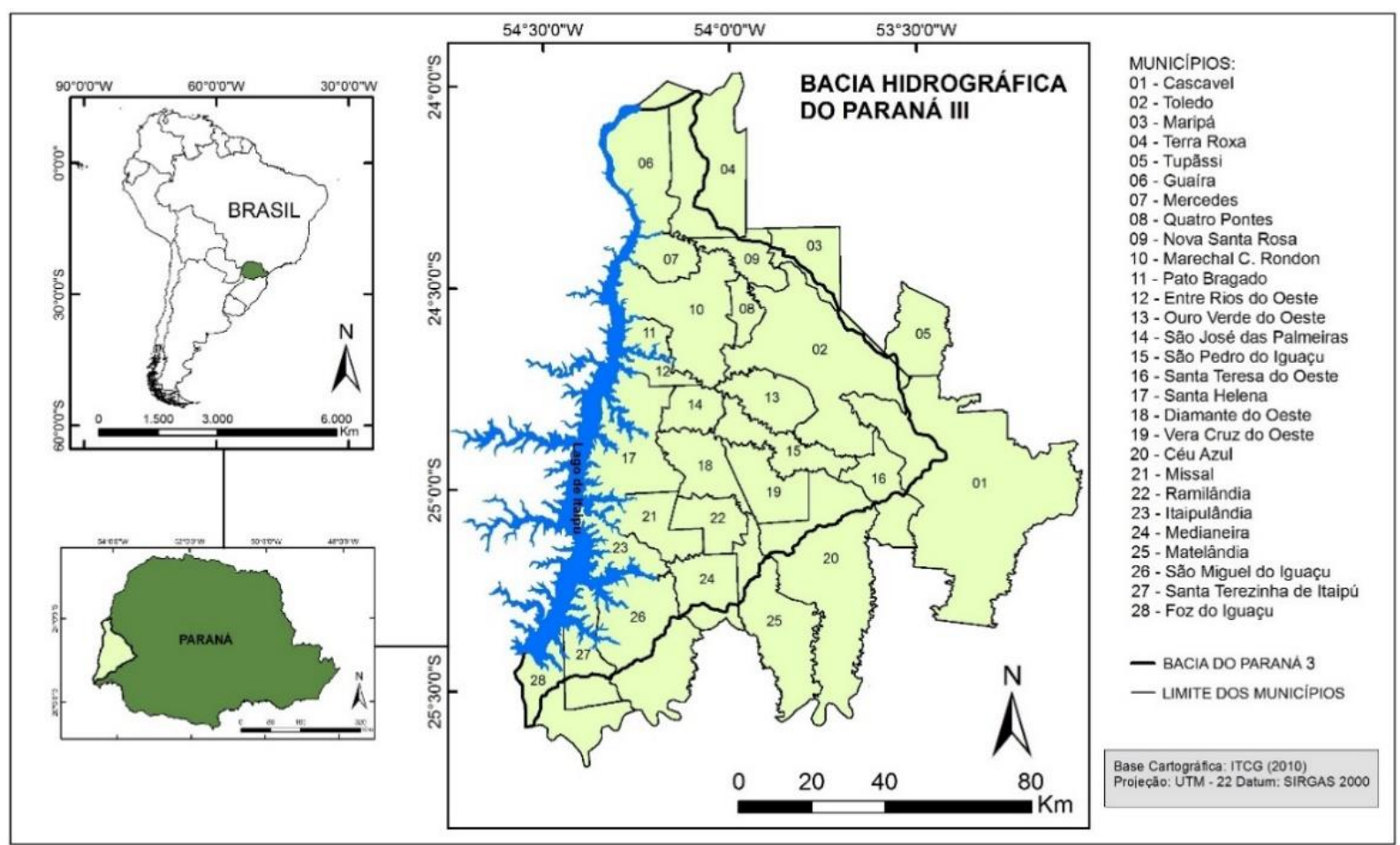


A BP3 compreende um conjunto de bacias com direcionamento de drenagem de Leste para Oeste, tributárias do rio Paraná, que desaguam diretamente no Reservatório do Lago de Itaipu. A BP3 é subdividida em 12 sub-bacias, abrangendo os cursos principais dos rios Taturi, Chororó, Guaçu, Marreco, São Francisco Verdadeiro, Santa Quitéria, São Francisco Falso Braço Norte, São Francisco Falso Braço Sul, São Vicente, Ocoí, Pinto e Passo-Cuê (Figura 2).

Figura 2: Geologia e Hidrografia da Bacia Hidrográfica do Paraná 3.

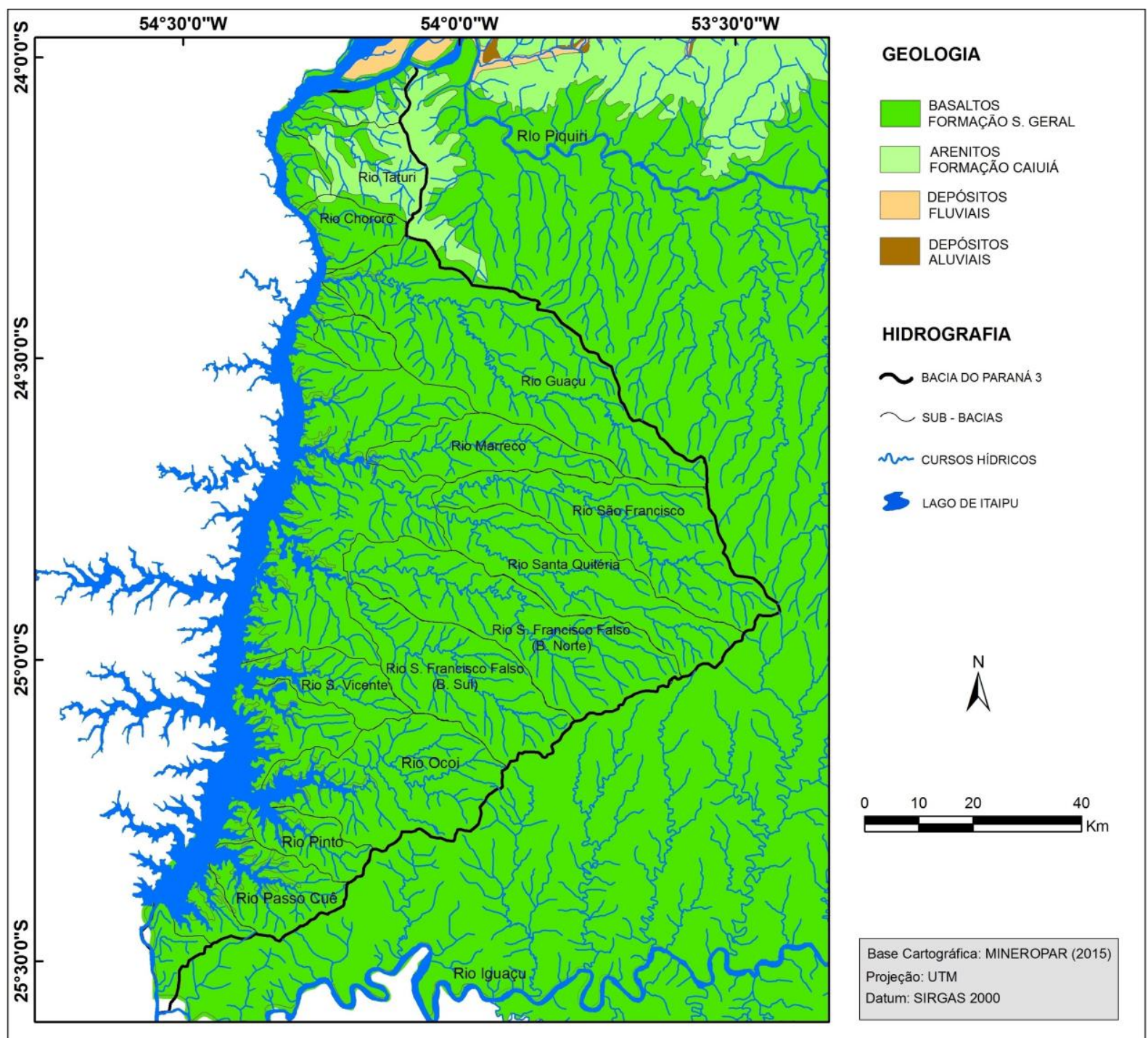

A unidade hidrográfica localiza-se no interior da Bacia Sedimentar do Paraná, no setor Oeste do Terceiro Planalto paranaense, onde o substrato geológico é constituído predominantemente por rochas basálticas da Formação Serra Geral, formadas pelos derrames vulcânicos do perío do Mesozóico. Ao Norte da bacia, observa-se uma zona de contato entre rochas ígneas efusivas e as rochas sedimentares compostas por arenitos da Formação Caiuá, também do Mesozóico (SANTOS et al., 2006; MINEROPAR, 2015).

Na maior parte da área da bacia predominam os solos de textura argilosa, oriundos da formação basáltica, classificados de Latossolos Vermelhos Eutroférricos, Latossolos Vermelhos Distroférricos e Nitossolos Vermelhos Eutroférricos em associação com os Neossolos Litólicos e Regolíticos. Entretanto, ao norte, na zona de contato do basalto com o arenito da Formação \begin{tabular}{llllll}
\hline Caminhos de Geografia & Uberlândia - MG & v. 19, n. 68 & Dez/2018 & p. 266-285 & Página 269
\end{tabular} 
Caiuá, ocorre uma pequena mancha de solos de textura média com predominância dos Latossolos Vermelhos Eutróficos e Argissolos Vermelhos Eutróficos. Os Gleissolos Háplicos e os Organossolos Háplicos também aparecem, mas em pequenas áreas planas e alagadiças, às margens do Rio Paraná.

Em relação ao uso e cobertura da terra, verifica-se que a BP3 contempla, principalmente, usos agrícolas e pecuários. Essa realidade evidencia a necessidade de estudos voltados às práticas de uso e manejo adequadas a capacidade das terras, sobretudo pelo contexto econômico e ambiental regional, essencialmente agropecuário.

\section{METODOLOGIA}

Para retratar as potencialidades ecológicas da bacia, recorreu-se à elaboração de cartas temáticas para obtenção de dados da estrutura geoecológica. Foram desenvolvidos mapas de solo, geologia, declividade, hipsometria, curvatura vertical e uso e cobertura da terra. Em seguida foram empregados os critérios de identificação das classes de capacidade de uso da terra, utilizando-se dos preceitos metodológicos propostos por Lepsch et al. (2015).

A produção de material cartográfico e a manipulação dos dados, associados à elaboração de cartas temáticas e cartas de capacidade de uso da terra da área de abrangência da BP3, ocorreu com a utilização do software ArcGis 9.3.

Para elaboração da carta pedológica, foi utilizada a base cartográfica do Mapa de Solos do Estado do Paraná (BHERING et al., 2008). Para a elaboração da carta geológica foi utilizado o Mapa Geológico do Paraná (MINEROPAR, 2015). As informações sobre a cobertura pedológica e as formações geológicas foram obtidas na escala de 1:250.000, por meio do site do Instituto de Terras Cartografia e Geologia do Paraná (ITCG, 2013), em formato shapefile.

As cartas temáticas de hipsometria e declividade foram elaboradas a partir dos dados da missão SRTM (Shuttle Radar Topography Mission). Para tanto construiu-se um mosaico a partir das imagens com resolução espacial de ( 30m): 23s555, 23s54, 24s555, 24s54, 25s555 e 25s54, disponibilizadas pelo Instituto Nacional de Pesquisas Espaciais através do projeto Topodata (INPE, 2016).

O mapeamento de uso e cobertura da terra foi obtido a partir da análise de imagens do satélite Landsat 8 , com cenas orbitais do ano de 2015, também disponibilizadas pelo INPE (2015). Com a utilização do software ArcGis 9.3, foram geradas as composições coloridas (RGB), utilizando as bandas 4,5 e 6 . Em seguida, utilizou-se a metodologia de classificação supervisionada, por meio do classificador MAXVER (Maximum Likelihood Classification). Esses procedimentos permitiram identificar as classes de vegetação, agricultura, pastagem e corpos hídricos da BP3. Para a identificação detalhada das áreas urbanas, recorreu-se à vetorização manual da imagem RGB.

\section{CLASSIFICAÇÃo dOS SOLOS NO SISTEMA DE CAPACIDADE DE USO}

A classificação das terras, no sistema de capacidade de uso, foi realizada com base na distribuição espacial das classes de solos existentes na bacia. A identificação das classes de solos, considerando os níveis categóricos (ordem, subordens e grandes grupos) do SiBICS (EMBRAPA, 2013), serviu de base cartográfica para a avaliação dos critérios diagnósticos e dos fatores restritivos de capacidade de uso.

Seguindo as recomendações de Lepsch et al. (2015), foram avaliados, em cada classe de solo, os critérios diagnósticos obrigatórios que compõem a fórmula mínima: profundidade efetiva do solo, textura, permeabilidade, declividade e erosão, assim como fatores restritivos associados à presença de hidromorfismo e os riscos de inundação. A avaliação dos critérios diagnósticos e dos fatores restritivos (Quadro 1), permitiram determinar as classes e subclasses de capacidade de uso (Quadro 2).

$\begin{array}{llllll}\text { Caminhos de Geografia } & \text { Uberlândia - MG } & \text { v. 19, n. } 68 & \text { Dez/2018 } & \text { p. 266-285 } & \text { Página } 270\end{array}$


Mapeamento da capacidade de uso das terras na bacia hidrográfica do Paraná 3: contribuições para o planejamento rural e ambiental
Anderson Sandro da Rocha

Maria Teresa de Nóbrega José Edézio da Cunha Maicol Rafael Bade

Quadro 1: Critérios utilizados para a determinação das classes de capacidade de uso dos solos, segundo Lepsch et al. (2015).

\begin{tabular}{|c|c|c|c|c|c|c|c|c|c|c|c|c|}
\hline \multicolumn{5}{|c|}{ Limitações } & \multicolumn{8}{|c|}{ Classes de Capacidade de Uso } \\
\hline & & & & & $I$ & II & III & IV & $\mathbf{V}$ & VI & VII & VIII \\
\hline \multirow{5}{*}{\multicolumn{3}{|c|}{ Profundidade Efetiva }} & 1 & Muito profundo (> 2m) & $\mathrm{X}$ & & & & & & & \\
\hline & & & 2 & Profundo $(1-2 m)$ & & $\mathrm{X}$ & & & & & & \\
\hline & & & 3 & Pouco Profundo(0,5 - 1m) & & & $\mathrm{X}$ & & & & & \\
\hline & & & 4 & Raso $(0,25-0,5 m)$ & & & & $\mathrm{X}$ & & & & \\
\hline & & & 5 & Muito raso $(<0,25 \mathrm{~m})$ & & & & & & $\mathrm{X}$ & & \\
\hline \multirow{6}{*}{\multicolumn{3}{|c|}{ Textura }} & 1 & Muito argilosa & $\mathrm{X}$ & & & & & & & \\
\hline & & & 2 & Argilosa & $\mathrm{X}$ & & & & & & & \\
\hline & & & 3 & Média & & & $\mathrm{X}$ & & & & & \\
\hline & & & 4 & Siltosa & & & & $\mathrm{X}$ & & & & \\
\hline & & & 5 & Arenosa & & & & & $\mathrm{X}$ & & & \\
\hline & & & 6 & Solos orgânicos & & & & & & & $\mathrm{X}$ & \\
\hline \multirow{8}{*}{\multicolumn{3}{|c|}{ Permeabilidade }} & 1 & Excessivamente drenado & & & & $\mathrm{X}$ & & & & \\
\hline & & & 2 & Fortemente drenado & & & $\mathrm{X}$ & & & & & \\
\hline & & & 3 & Acentuadamente drenado & & $\mathrm{X}$ & & & & & & \\
\hline & & & 4 & Bem drenado & $\mathrm{X}$ & & & & & & & \\
\hline & & & 5 & Moderadamente drenado & & $\mathrm{X}$ & & & & & & \\
\hline & & & 6 & Imperfeitamente drenado & & & $\mathrm{X}$ & & & & & \\
\hline & & & 7 & Mal drenado & & & & $\mathrm{X}$ & & & & \\
\hline & & & 8 & Muito mal drenado & & & & & $\mathrm{X}$ & & & \\
\hline \multirow{6}{*}{\multicolumn{3}{|c|}{ Declividade }} & $\mathrm{A}$ & $0-3 \%$ & $\mathrm{X}$ & & & & & & & \\
\hline & & & $\mathrm{B}$ & $3-6 \%$ & & $\mathrm{X}$ & & & & & & \\
\hline & & & $\mathrm{C}$ & $6-12 \%$ & & & $\mathrm{X}$ & & & & & \\
\hline & & & $\mathrm{D}$ & $12-20 \%$ & & & & $\mathrm{X}$ & & & & \\
\hline & & & $E$ & $20-30 \%$ & & & & & & $\mathrm{X}$ & & \\
\hline & & & $\mathrm{F}$ & $>30 \%$ & & & & & & & $\mathrm{X}$ & \\
\hline \multirow{18}{*}{ Erosão } & & & 0 & Não aparente & $\mathrm{X}$ & & & & & & & \\
\hline & \multirow{5}{*}{\multicolumn{2}{|c|}{ Laminar }} & 1 & Ligeira & & $\mathrm{X}$ & & & & & & \\
\hline & & & 2 & Moderada & & & $\mathrm{X}$ & & & & & \\
\hline & & & 3 & Severa & & & & & & $\mathrm{X}$ & & \\
\hline & & & 4 & Muito severa & & & & & & & $\mathrm{X}$ & \\
\hline & & & 5 & Extremamente severa & & & & & & & & $\mathrm{X}$ \\
\hline & \multirow{12}{*}{ Sulcos } & \multirow{3}{*}{$\begin{array}{l}\text { Superficia } \\
\text { is }\end{array}$} & 7 & Ocasionais & & $\mathrm{X}$ & & & & & & \\
\hline & & & 8 & Frequentes & & & $\mathrm{X}$ & & & & & \\
\hline & & & 9 & Muito frequentes & & & & $\mathrm{X}$ & & & & \\
\hline & & \multirow{3}{*}{ Rasos } & 7 & Ocasionais & & & $\mathrm{X}$ & & & & & \\
\hline & & & 8 & Frequentes & & & & $\mathrm{X}$ & & & & \\
\hline & & & 9 & Muito frequentes & & & & & $\mathrm{X}$ & & & \\
\hline & & \multirow{3}{*}{$\begin{array}{l}\text { Profundo } \\
\mathbf{s}\end{array}$} & 7 & Ocasionais & & & & $\mathrm{X}$ & & & & \\
\hline & & & 8 & Frequentes & & & & & $\mathrm{X}$ & & & \\
\hline & & & 9 & Muito frequentes & & & & & & $\mathrm{X}$ & & \\
\hline & & \multirow{3}{*}{$\begin{array}{c}\text { Muito } \\
\text { Profundo } \\
\text { s } \\
\text { (Voçoroc } \\
\text { as) }\end{array}$} & 7 & Ocasionais & & & & & & $\mathrm{X}$ & & \\
\hline & & & 8 & Frequentes & & & & & & & $\mathrm{X}$ & \\
\hline & & & 9 & Muito frequentes & & & & & & & & $\mathrm{X}$ \\
\hline \multirow{4}{*}{\multicolumn{3}{|c|}{ Risco de Inundação }} & 0 & Sem risco & $\mathrm{X}$ & & & & & & & \\
\hline & & & 1 & Ocasional & & & $\mathrm{X}$ & & & & & \\
\hline & & & 2 & Frequente & & & & & & $\mathrm{X}$ & & \\
\hline & & & 3 & Muito frequente & & & & & & & & $\mathrm{X}$ \\
\hline \multirow{5}{*}{\multicolumn{3}{|c|}{ Hidromorfismo }} & 0 & Não aparente & $\mathrm{X}$ & & & & & & & \\
\hline & & & hi0 & $\begin{array}{l}\text { Presente, mas em grau } \\
\text { não identificado }\end{array}$ & & & $\mathrm{X}$ & & & & & \\
\hline & & & hi1 & Prof. $>100 \mathrm{~cm}$ & & & & $\mathrm{X}$ & & & & \\
\hline & & & hi2 & Prof. $(50-100 \mathrm{~cm})$ & & & & & $\mathrm{X}$ & & & \\
\hline & & & hi3 & Prof. $(25-50 \mathrm{~cm})$ & & & & & & $X$ & & \\
\hline
\end{tabular}


Quadro 2: Classes e subclasses de capacidade de uso dos solos, segundo Lepsch et al. (2015).

\begin{tabular}{|c|c|}
\hline \multicolumn{2}{|r|}{ Classes de Capacidade de Uso } \\
\hline Classe I & $\begin{array}{l}\text { Terras sem ou com ligeiras limitações permanentes em relação ao risco de degradação para o uso } \\
\text { agrícola intensivo. }\end{array}$ \\
\hline Classe II & $\begin{array}{l}\text { Terras com limitações permanentes e/ou risco de degradação em grau moderado para uso agrícola } \\
\text { intensivo; são terras cultiváveis com problemas simples de conservação. }\end{array}$ \\
\hline Classe III & $\begin{array}{l}\text { Terras com limitações permanentes e/ou risco de degradação em grau severo para uso agrícola } \\
\text { intensivo; são terras cultiváveis, mas apresentam problemas complexos de conservação. }\end{array}$ \\
\hline Classe IV & $\begin{array}{l}\text { Terras com limitações permanentes e/ou risco de degradação em graus muito severos se usados } \\
\text { para cultivos intensivos; devem ser apenas cultiváveis ocasionalmente ou com extensão limitada, } \\
\text { com a escolha de exploração adequadas. }\end{array}$ \\
\hline Classe V & $\begin{array}{l}\text { Terras sem ou com pequeno risco de degradação pela erosão, mas com outras limitações não } \\
\text { possíveis de serem removidas e que podem fazer com que seu uso seja limitado apenas para } \\
\text { pastagens, reflorestamentos ou vida silvestre. }\end{array}$ \\
\hline Classe VI & $\begin{array}{l}\text { Terras com limitações permanentes e/ou risco de degradação em grau severo, que fazem com que } \\
\text { possam ser usadas somente para pastagens e/ou reflorestamento, ou ainda, em casos especiais, } \\
\text { com certas culturas permanentes protetoras do solo. }\end{array}$ \\
\hline Classe VII & $\begin{array}{l}\text { Terras com limitações permanentes e/ou risco de degradação em grau muito severo, mesmo quando } \\
\text { usadas para pastagens e/ou reflorestamento, que devem no caso, ser manejadas com extremo } \\
\text { cuidado. }\end{array}$ \\
\hline Classe VIII & $\begin{array}{l}\text { Terras impróprias para culturas, pastagens ou reflorestamentos, por isso devem ser destinadas ao } \\
\text { abrigo e à proteção da fauna e flora silvestre, aos ambientes de recreação protegidos, bem como } \\
\text { para armazenamento de água. }\end{array}$ \\
\hline \multicolumn{2}{|r|}{ Subclasses de Capacidade de Uso } \\
\hline e-relevo & $\begin{array}{l}\text { Limitações relativas ao relevo, com restrições principalmente associadas ao declive acentuado e a } \\
\text { presença de erosão e/ou de risco potencial. }\end{array}$ \\
\hline s - solo & Limitações relativas ao solo, com restrições associadas a baixa profundidade e a textura do solo. \\
\hline a-água & $\begin{array}{l}\text { Limitações relativas a água, com restrições associadas a presença de hidromorfismo, risco de } \\
\text { inundação e lençol freático elevado. }\end{array}$ \\
\hline c-clima & $\begin{array}{l}\text { Limitações relativas ao clima, com restrições associadas a áreas com seca prolongada ou risco de } \\
\text { geada, granizo e neve. }\end{array}$ \\
\hline
\end{tabular}

Para a elaboração do mapa de capacidade de uso das terras, foram avaliadas individualmente cada classe de solo do primeiro ao terceiro nível categórico. Em cada classe de solo foram analisados os parâmetros de profundidade efetiva do solo, textura, permeabilidade, declividade, ocorrência de erosão, presença de hidromorfismo e os riscos de inundação. A atribuição dos parâmetros basearamse nos trabalhos de mapeamento e classificação dos solos desenvolvidos na BP3 (ROCHA, 2016; BATISTA, 2018; SANCHES 2018) e nos critérios diagnósticos do Sistema Brasileiro de Classificação dos Solos (EMBRAPA, 2013). Para cada classe de solo e para cada parâmetro de análise, foi atribuído uma classe de capacidade de uso, utilizando-se das recomendações sugeridas por Lepsch et al. (2015), descritas nos quadros 1 e 2 . Na sequência foi estruturado um quadro contendo as dez classes de solo presentes na bacia, onde cada classe de solo recebeu uma atribuição de classe/subclasse de capacidade (Quadro 3). A identificão das classes/subclasses estruturada no quadro 3, permitiu verificar a capacidade de uso e os fatores restritivos dominante em cada tipo de solo. Dessa forma foi criada uma nova coluna na tabela de atributos do arquivo shapefile de solo, nessa coluna foi acrescentada a classe/sublasse de capacidade de uso determinada para cada tipo de solo. A coluna de capacidade de uso recebeu a sigla (CAP_USO). Dessa forma cada classe de capacidade de uso presente na coluna CAP_USO, recebeu uma cor específica de acordo com o sistema de cores proposto por Lepsch et al. (2015). A atribuição das cores em cada classe/subclasse possibilitou espacializar e elaborar o mapa de capacidade de uso das terras (Figura 7). 


\section{RESULTADOS E DISCUSSÃO}

\section{A DISTRIBUIÇÃO ESPACIAL DA COBERTURA PEDOLÓGICA, AS CONDIÇÕES TOPOGRÁFICAS E O USO DA TERRA NA BACIA HIDROGRÁFICA DO PARANÁ 3}

A correlação das cartas de solo, hispsometria e declividade (Figuras 3, 4 e 5), com o uso e cobertura da terra (Figura 6), possibilitou verificar que a distribuição da cobertura pedológica na BP3 pode ser caracterizada em três grandes setores, o superior, o intermediário e o inferior da bacia. Esses setores representam domínios morfopedológicos que implicam em diferentes formas de uso e manejo, bem como de capacidade de uso.

O setor superior (localizado entre as altitudes de 500 e 800 metros) caracteriza-se predominantemente por colinas amplas a médias com topos planos, alongados e vales em $\mathrm{V}$, modelados por vertentes convexo-retilíneas com declividades que variam entre $0-12 \%$. Nesse setor os Latossolos Vermelhos Distroférricos, ocorrem em declividades entre $0-6 \%$, predominantemente no segmento de alta e média vertente e os Nitossolos Vermelhos Eutroférricos no segmento baixo da vertente, onde as declividades apresentam entre 6 e 12\%. Em geral, o domínio da topografia suave ondulada, dos solos profundos e altamente intemperizados, favorecem a agricultura temporária, comumente praticada de modo intensivo e altamente mecanizado.

Figura 3: Carta de Solos da Bacia Hidrográfica do Paraná 3.

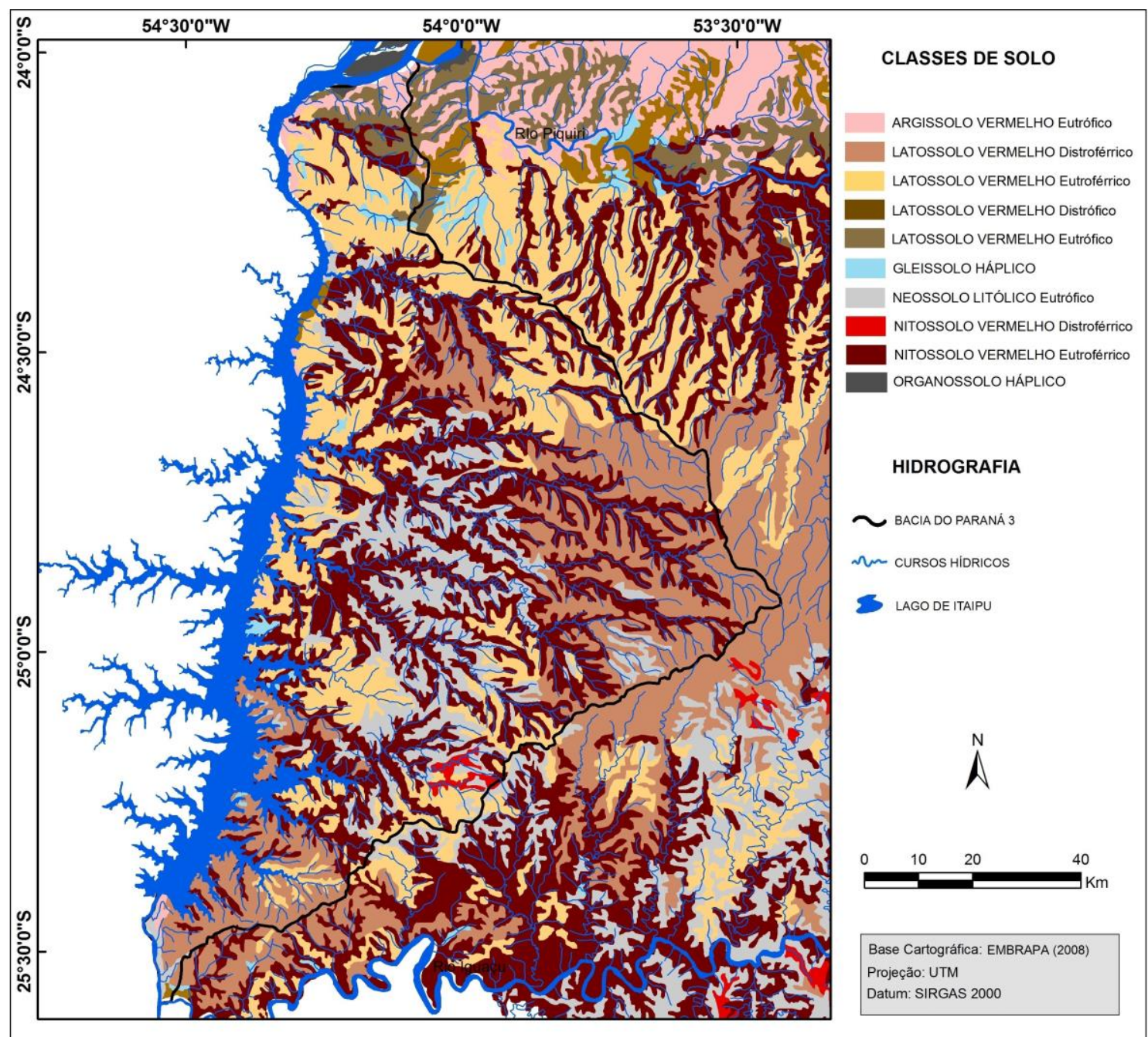


Figura 4: Carta Hipsométrica da BP3.

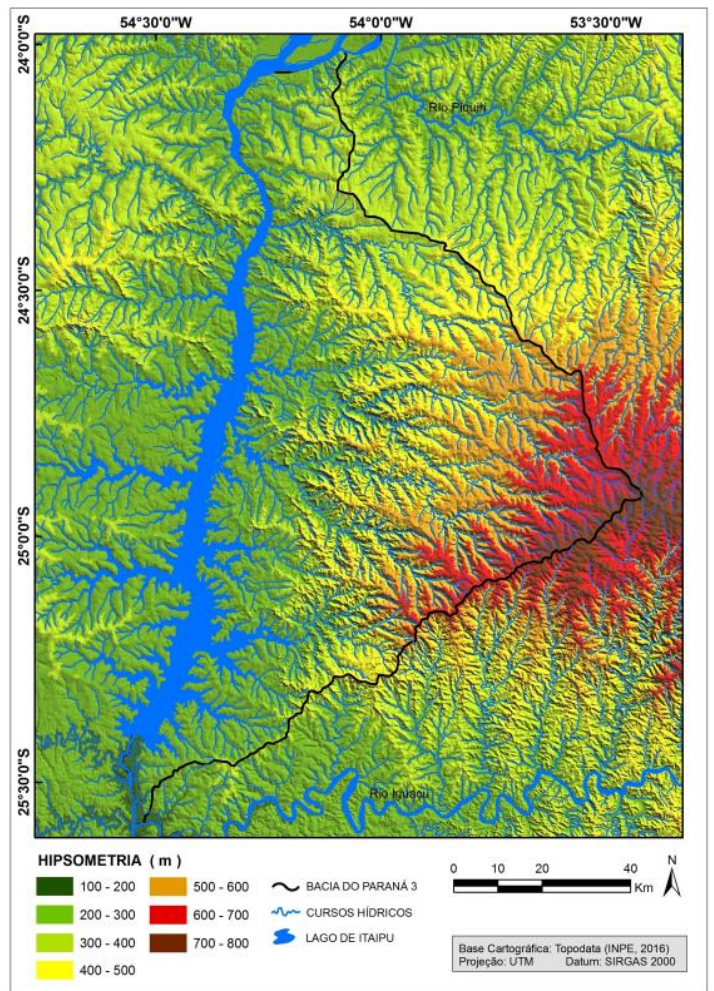

Figura 5: Carta de Declividade da BP3.

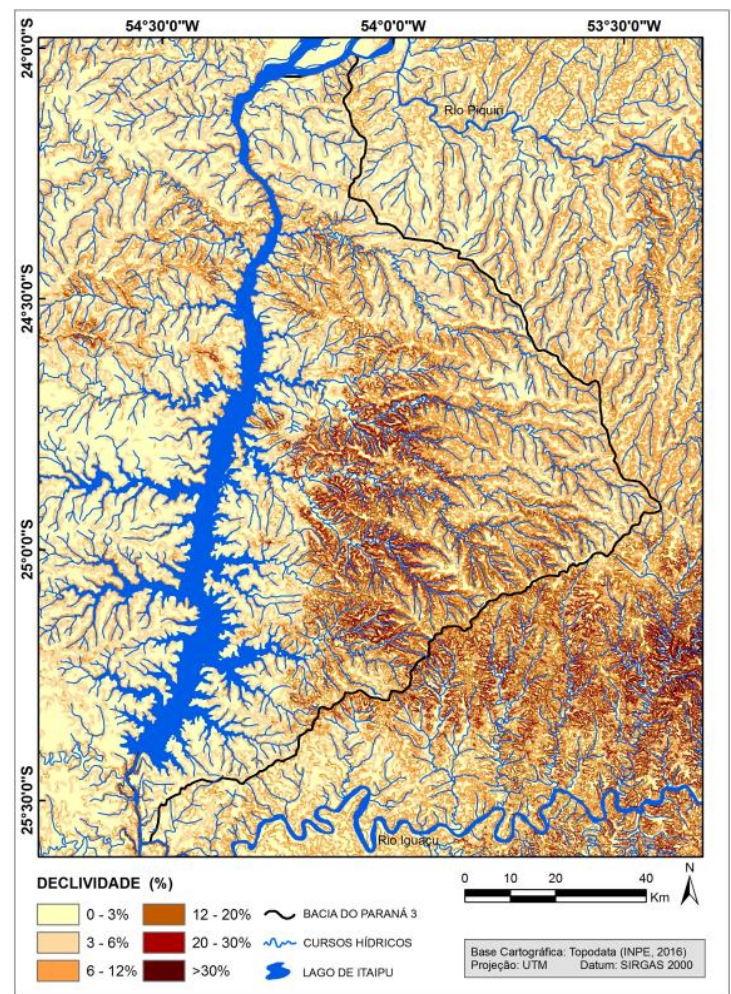

O setor intermediário da unidade hidrográfica, onde predominam altitudes entre 300 e 500 metros, situado ao longo dos cursos médios dos rios São Francisco Verdadeiro, Santa Quitéria, São Francisco Falso Braço Norte e Sul, representa o ambiente geomorfológico de maior dissecação da bacia. Esse compartimento exibe espigões estreitos dispostos de Leste para Oeste, modelados pelo encaixe dos cursos principais. As vertentes são convexo-côncavas e convexo-retilíneas, muitas vezes, segmentadas em patamares, alternando declividades fracas e muito fortes - entre 6 e $30 \%$. Os topos dos níveis topográficos, embutidos entre os espigões principais, são curtos e estreitos e os vales em $\mathrm{V}$ e $\mathrm{U}$, conferindo um aspecto geral de relevo amorreado.

Nesse setor intermediário, a cobertura pedológica reflete as variações das formas e das declividades. Nos setores de vertentes compostos por rupturas, seguidas de formas convexas e segmentos retilíneos com declividades de 12 a $20 \%$ e de 20 a 30\%, é comum a presença dos Neossolos Litólicos e/ou Regolíticos (Eutróficos). Já nos setores de vertentes compostos por formas côncavas, associadas a segmentos retilíneos com declividades entre 6-12\%, verifica-se a presença dos Nitossolos Vermelhos Eutroférricos. A porção intermediária compõe a área de maior dissecação da bacia, onde são comuns solos rasos, predominantemente ocupados por pastagens, em associação com cultivos agrícolas e vegetação florestal.

O setor inferior da unidade hidrográfica, localizado às margens do Rio Paraná, entre 100 e 300 metros de altitude, contempla um ambiente geomorfológico de menor dissecação. É basicamente composto por colinas médias a amplas, topos largos e achatados e vertentes convexo-retilíneas, com declividades muito fracas, predominante entre $0-3 \%$, formando vales em $\mathrm{V}$ muito abertos. Nesse setor ocorre a presença do Latossolo Vermelho Eutroférrico na alta e média-alta vertente e do Nitossolo Vermelho Eutroférrico no segmento médio-baixo e baixo. Ao longo de todo o setor rebaixado da unidade, os vales apresentam-se abertos e os fundos exibem formas planas e, às vezes, ligeiramente côncavas. Esses vales, quando expostos a condições de hidromorfia, podem apresentar a ocorrência de solos Gleissolos e Organossolos Háplicos, geralmente associados ao excedente hídrico que ocorre às margens do Lago de Itaipu.

\begin{tabular}{llllll}
\hline Caminhos de Geografia & Uberlândia - MG & v. 19, n. 68 & Dez/2018 & p. 266-285 Página 274
\end{tabular}


Localmente, às margens do rio Paraná verificam-se manchas de Argissolo Vermelho Eutrófico. Os Argissolos também se destacam na porção norte da bacia, onde ocorrem em associação com os Latossolos Vermelhos (Distróficos e Eutróficos) de textura média, ambiente em que se verifica a zona de contato entre os arenitos da Formação Caiuá e as rochas ígneas efusivas basálticas da Formação Serra Geral. O uso da terra, nessa porção da unidade hidrográfica, é predominantemente agrícola, resultante do aproveitamento da topografia caracterizada pelas fracas declividades e dos solos favoráveis aos cultivos temporários mecanizados. Destaca-se ainda nesse setor um relevante papel da piscicultura associada ao potencial hídrico disponível em razão da formação do lago de Itaipu na região.

Em termos gerais, verifica-se que o uso e cobertura da terra na unidade hidrográfica do Paraná 3 contempla, principalmente, os usos agrícolas e pecuários, com domínios regionais nos três grandes setores (Figura 6).

A agricultura compõe a classe de uso dominante e abrange cerca de $70 \%$ da área total da bacia. Os cultivos agrícolas são de soja, milho, trigo e aveia e apresentam sistema de manejo de plantio direto. A distribuição das áreas agrícolas encontra-se especialmente associada aos setores de relevo com baixa dissecação e solos mais profundos, localizados nos setores alto e baixo da bacia.

A atividade pecuária, representada pelos setores compostos por áreas de pastagens, ocupa pouco mais de $2 \%$ da área de estudo. Esses setores normalmente exibem o manejo de gado (corte e leiteiro) de forma extensiva. Em termos de localização, as pastagens ocupam basicamente o setor intermediário da bacia, onde predominam alta dissecação do relevo e solos rasos. No setor norte da bacia, também se verifica uma estreita faixa com pastagem associada às áreas recobertas com solos de textura média, oriundos do arenito da Formação Caiuá.

Figura 6. Carta de Uso e Cobertura da Terra na Bacia Hidrográfica do Paraná 3.

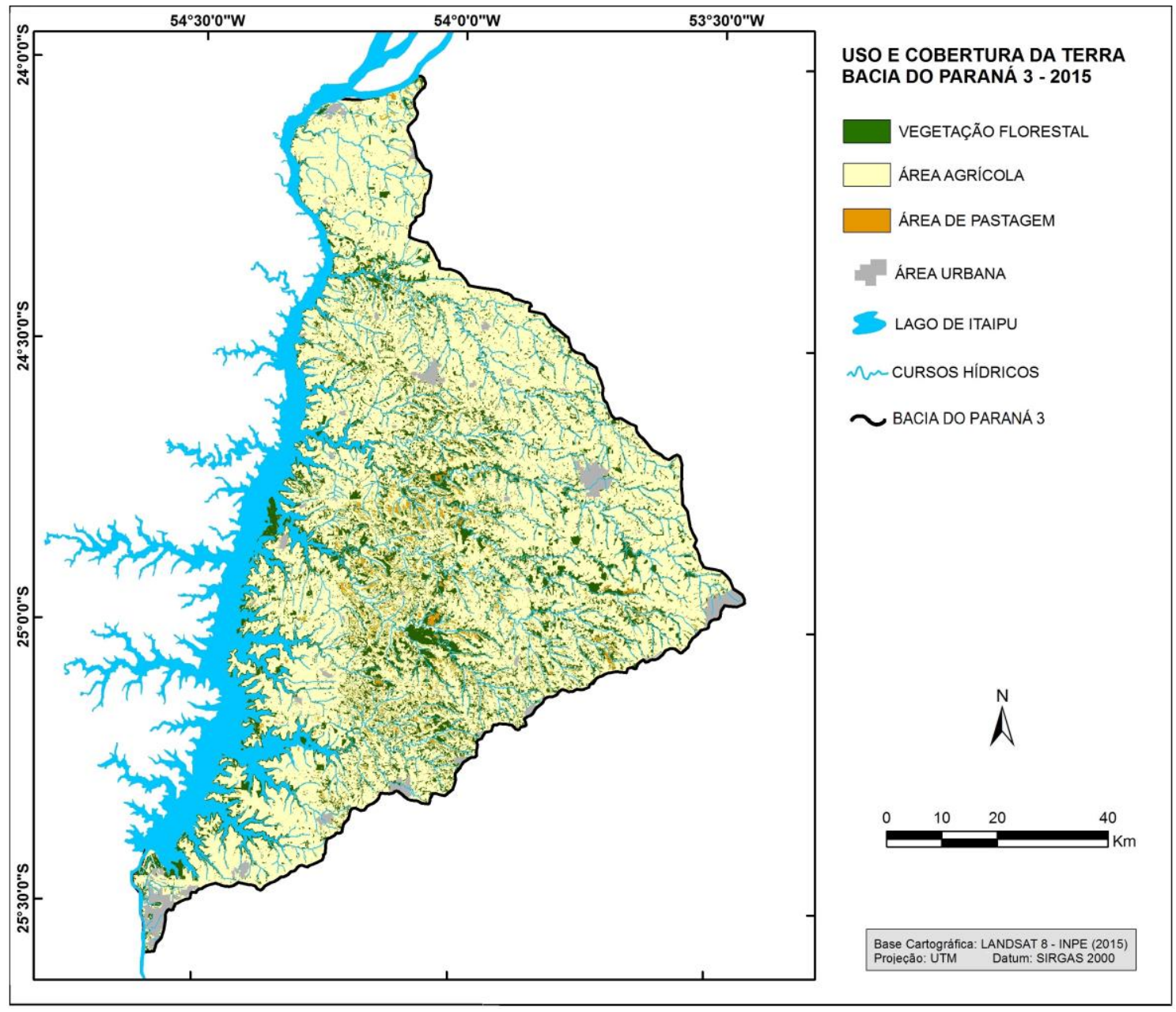


Os remanescentes florestais da BP3 distribuem-se principalmente às margens dos principais cursos hídricos, assim como em setores onde há maiores limitações físico-naturais (altas declividades e solos de baixa fertilidade natural) que impedem o desenvolvimento de atividades antrópicas. Embora a vegetação natural tenha sido devastada no processo de ocupação, verificase uma área representativa de mata (natural e reflorestada), ao longo da bacia. Atualmente a vegetação ocupa uma área superior a $16 \%$ do total.

A margem esquerda do reservatório de Itaipu, juntamente com os afluentes do Rio Paraná situados em território brasileiro, soma uma área de aproximadamente $618 \mathrm{~km}^{2}$. Esta relevante área, composta por corpos hídricos, reflete a magnitude da área alagada, responsável pelo expressivo percentual de corpos hídricos, superior a $7 \%$ do total da área de estudo. Já as áreas urbanizadas, ocupam cerca de $2 \%$, sendo que as principais sedes municipais se localizam em sua maioria nas regiões limítrofes aos divisores de água da bacia.

O conhecimento da distribuição espacial do uso da terra, assim como da organização da cobertura pedológica da área, considerando as variáveis geológicas e geomorfológicas, possibilita estabelecer diversas relações em termos de capacidade de uso.

\section{CAPACIDADE DE USO DA TERRA NA BP3: RECOMENDAÇõES E RESTRIÇõeS AMBIENTAIS}

Para representar, espacialmente e quantitativamente as potencialidades agrícolas e pecuárias, e diagnosticar as áreas de restrição ambiental da área de estudo, utilizou-se como base dez diferentes classes de solos (Quadro 3), por meio dos quais foram determinadas as classes e subclasses de capacidade de uso, segundo os parâmetros sugeridos por Lepsch et al. (2015). Os domínios de solos apresentaram diferenças significativas em termos de recomendações de uso.

Quadro 3: Determinação das classes e subclasses de capacidade de uso da BP3.

\begin{tabular}{|c|c|c|c|c|c|c|c|c|c|c|}
\hline \multirow{2}{*}{$\begin{array}{c}\text { Classes } \\
\text { de } \\
\text { Solos }\end{array}$} & \multicolumn{8}{|c|}{ Atributos de Análise } & \multirow{2}{*}{$\begin{array}{c}\text { Classes } \\
\text { Cap. } \\
\text { Uso }\end{array}$} & \multirow[t]{2}{*}{$\begin{array}{c}\text { Sub- } \\
\text { classes }\end{array}$} \\
\hline & Prof. & Text. & Perm. & Decli. & $\begin{array}{l}\text { Erosão } \\
\text { Laminar }\end{array}$ & $\begin{array}{l}\text { Erosão } \\
\text { Sulcos }\end{array}$ & $\begin{array}{l}\text { Risco } \\
\text { Inun. }\end{array}$ & Hidro. & & \\
\hline $\mathrm{PVe}$ & 1 & III & II & II & II & 1 & $I$ & $I$ & III & IIIs,e \\
\hline LVdf & I & I & $\mathrm{I}$ & II & I & $\mathrm{I}$ & $\mathrm{I}$ & $\mathrm{I}$ & II & Ile \\
\hline LVd & I & III & II & II & II & I & I & 1 & III & IIIs,e \\
\hline LVef & I & I & I & II & I & $\mathrm{I}$ & I & I & II & Ile \\
\hline LVe & I & III & II & II & II & I & $\mathrm{I}$ & I & III & IIIs,e \\
\hline$G X$ & III & I & IV & I & I & I & VI & VI & VI & VIs,a \\
\hline RLe & IV & I & I & VI & III & III & I & 1 & VI & VIs,e \\
\hline NVef & $\mathrm{I}$ & $\mathrm{I}$ & $\mathrm{I}$ & III & $\mathrm{I}$ & II & $\mathrm{I}$ & $\mathrm{I}$ & III & Ille \\
\hline NVdf & $\mathrm{I}$ & 1 & I & III & $\mathrm{I}$ & II & $\mathrm{I}$ & I & III & Ille \\
\hline OX & IV & VII & $\mathrm{V}$ & I & I & I & VIII & VII & VIII & VIIIs,a \\
\hline
\end{tabular}

A avaliação da capacidade de uso da terra permitiu identificar quadro classes e seis subclasses na área de abrangência da unidade hidrográfica do Paraná 3.

A classe dominante é a classe III (representada pelas subclasses IIle, dominante, e IIIs,e) que soma um total de $43,39 \%$ da área, seguida da classe II (subclasse lle), que abrange $41,92 \%$ da área em estudo. Destacam-se também a classe VI (subclasses VIs,e e VIs,a) com cerca de 15\%, enquanto a classe VIII (subclasse VIIIs,a) representa menos de $1 \%$ da área total da unidade hidrográfica (Tabela 1 - Figura 7). 
Tabela 1: Área ocupada pelas classes de Capacidade de Uso da Terra da BP3.

\begin{tabular}{cc}
\hline $\begin{array}{c}\text { Classes e Subclasses de } \\
\text { Capacidade de Uso }\end{array}$ & Área Ocupada (\%) \\
\hline Ile & 41,92 \\
Ille & 38,28 \\
Ills,e & 5,11 \\
Vls,e & 13,55 \\
Vls, a & 1,05 \\
VIIls,a & 0,09 \\
Total & 100,00 \\
\hline
\end{tabular}

Figura 7: Capacidade de uso das terras da Bacia Hidrográfica do Paraná 3.

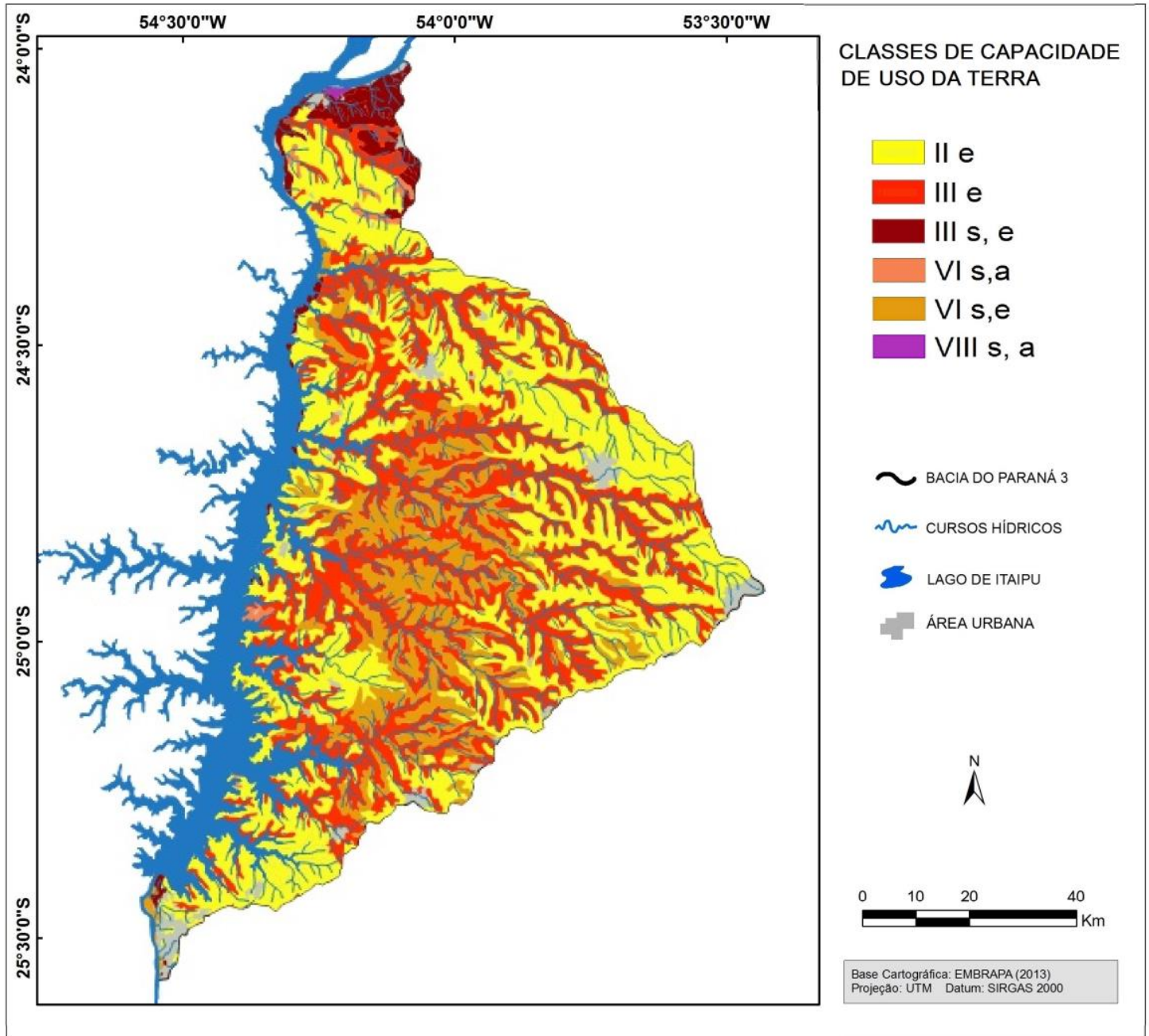

A subclasse lle engloba as terras próprias para uma grande diversidade de culturas agrícolas, pecuária ou floresta, com a recomendação de práticas simples de conservação do solo. Nesta subclasse, os solos são compostos por Latossolos Vermelhos (Eutroférricos e Distroférricos), com declividades predominantes entre 3 e $6 \%$ e vertentes de formas convexas e retilíneas. Destaca-se, 
contudo, a adoção necessária de práticas simples como o plantio direto em curvas de nível, principalmente recomendadas para os setores alto e baixo da bacia (Figura 7).

A subclasse Ile, ocorre predominantemente em solos profundos e relevos de baixa declividade. Essas condições, favorecem os cultivos temporários desenvolvidos no contexto atual, normalmente composto por soja, milho e trigo. Nesses setores pode-se verificar que o uso agrícola e as práticas de conservação, particularmente associadas as técnicas de plantio direto e terraceamento são compatíveis com a capacidade de uso recomendada. Os locais onde foram indicadas a subclasse lle, situam-se nos segmentos de alta e média vertente e distribuiem-se principalmente nos setores Leste, Oeste e Norte da bacia. Nesses setores não foram verificados problemas associados a erosão linear como sulcos, ravinas e voçorocas, evidenciando que, as técnias agrícolas empregadas tem controlado os problemas associdados a erosão ocorridas no passado, principalmente nas décadas de 1960 e 1970, quando eram empregadas as técnicas de plantio convencional. A partir desse período até o contexto atual, o emprego do plantio direto na palha e o cultivo em nível, tem controlado os processos de erosão nos setores de alta e média vertente, sobretudo em áreas com baixa declividade, como as que são encontradas na subclasse II.

As subclasses Ille e IIIs,e também contemplam terras viáveis para diferentes tipos de culturas, porém com necessidade de práticas mais intensivas ou mesmos complexas de conservação do solo. A subclasse Ille abrange apenas solos argilosos do tipo Nitossolo Vermelho (Eutroférricos e Distroférricos), porém apresenta declividade entre 6 e 12\%, ocupando especialmente o terço inferior das vertentes. Essas áreas, embora não apresentem restrição em relação ao solo, compõem setores topograficamente mais frágeis devido à maior inclinação e à sua posição na vertente. Já a subclasse IIIs,e corresponde aos solos de textura média, com destaque para os Latossolos Vermelhos (Distróficos e Eutróficos) e Argissolos Vermelhos Eutróficos. Dessa forma, os setores que englobam estas subclasses devem, segundo Lepsch et al. (2015), contar com práticas mais intensivas, como o plantio e cultivo em nível, rotação de culturas ou práticas ainda mais complexas, como canais de escoadouros, incorporação de matéria orgânica no solo e plantio intercalado de culturas temporárias, com culturas permanentes de raízes mais profundas.

Cabe ressaltar que as subclasses Ille e IIls,e apresentam-se distribuídas de forma diferenciadas ao longo da BP3. A primeira ocupa os principais segmentos de baixa vertente, as margens dos principais cursos hídricos, ou ainda áreas de topos estreitos na região central. Enquanto a última ocorre principalmente na porção Norte da unidade hidrográfica, em setores onde os solos apresentam textura média.

Os setores onde ocorrem a subclasse Ille, composto por solos de textura argilosa, são dominantemente ocupados por culturas temporárias com prática de plantio direto. Já os setores onde ocorrem a subclasse IIls,e além das culturas temporárias de soja e miho, também se verificam pontuamente atividades pecuárias, normalmente representada pela pastagem, utilizada para criação de gado de corte. Em ambos os setores, embora o uso agrícola e pecuário seja compatível com as recomendações de capacidade de uso, foram verificados indícios de degradação do solo, tendo em vista a presença de processos erosivos lineares como sulcos e ravinas, observados particularmente nos segmentos de baixa vertente.

A degradação dos solos por meio dos processos erosivos verficados nos setores de baixa vertente, tanto em solos de textura argilosa, como arenosa é decorrente da falta e/ou inadequada utilização das práticas de conservação do solo. Sobre está temática diferentes estudos desenvolvidos na Bacia Hidrográfica do Paraná 3 (ROCHA et al., 2016; BATISTA, 2018; SANCHES, 2018) destacam que os processos lineares evidenciados nos segmentos inferiores da vertente, encontram-se associados a problemas como a falta de rotação de cultura, dimensionamento inadequado do terraceamento e a compactação do solo nos horizontes superficiais. Dessa forma pode-se constatar que as áreas mapeadas com as subclasses Ille e Ills,e apresentam compatibilidade de uso, porém há evidência de problemas relevantes associados as práticas de conservação do solo.

Segundo a EMBRAPA (2018) a adoção do sitema de plantio direto (SPD) implantado no Paraná na década de 1970, foi capaz de reduzir em até $95 \%$ as perdas por erosão, comparada ao sistema de plantio convencional (SPC). No entanto as pesquisas desenvolvidas pela Embrapa nas ultimas três décadas destacam que o uso inadequado ou parcial do sitema de plantio direto no estado, principalmente com a baixa produção de palha e raízes pela adoção de sistemas pouco diversificado (soja/milho), associado ao rebaixamento dos terraços, utilização parcial ou ainda a falta de manutenção das curvas de nível, tem trazido novamente o desenvolvimento e evolução de processos 
erosivos como sulcos e ravinas, principalmente nos nos setores baixa vertente e áreas de moderada declividade. Em decorrência do retorno dos processos erosivos lineares associados aos períodos de maior precipitação, evidenciados no estado e particularmente na Bacia Hidrográfica do Paraná 3, tem se verificado nos últimos anos, uma preocupação com a implantação de técnicas de conservação e manejo do solo, visando principalmente o dimensionamento correto das curvas de nível, considerando a declividade e textura do solo. Nesse sentido, alguns órgãos regionais e estaduais têm apresentado programas e implementado práticas de conservação visando a recomposição dos terraços de base larga visando a contenção de processos erosivos laminares e lineares (Figuras 8 e 9). Dessa forma, além do dimensionamento adequado dos terraços, pode se propor para essas áreas onde se encontram as subclasses Ille e IIls,e uma maior rotatividade de culturas, implantação de cultivos em faixa nas áreas de moderada declividade, incorporação de matéria orgânica no solo, implantação de culturas específicas que auxiliem da descompactação do solo e maior fiscalização dos orgãos competentes em relação ao terraceamento e o controle de erosão.

Figura 8: Erosão em sulcos em área de baixa vertente (subclasse Ille).

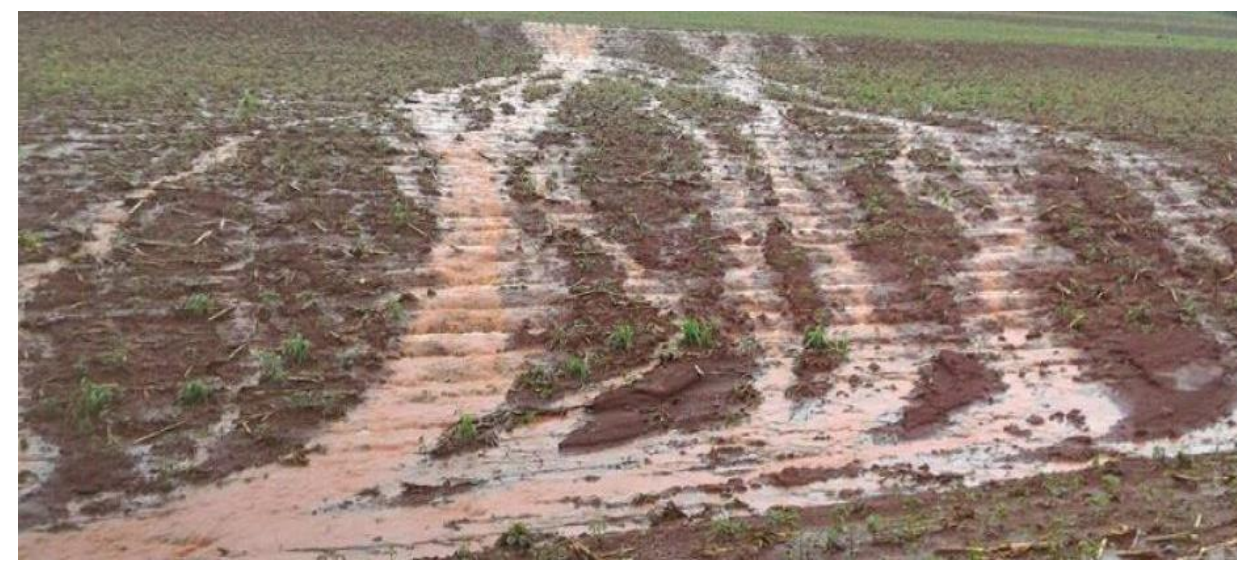

Figura 9: Readequação dos terraços em áreas de baixa vertente (subclasse IIle).

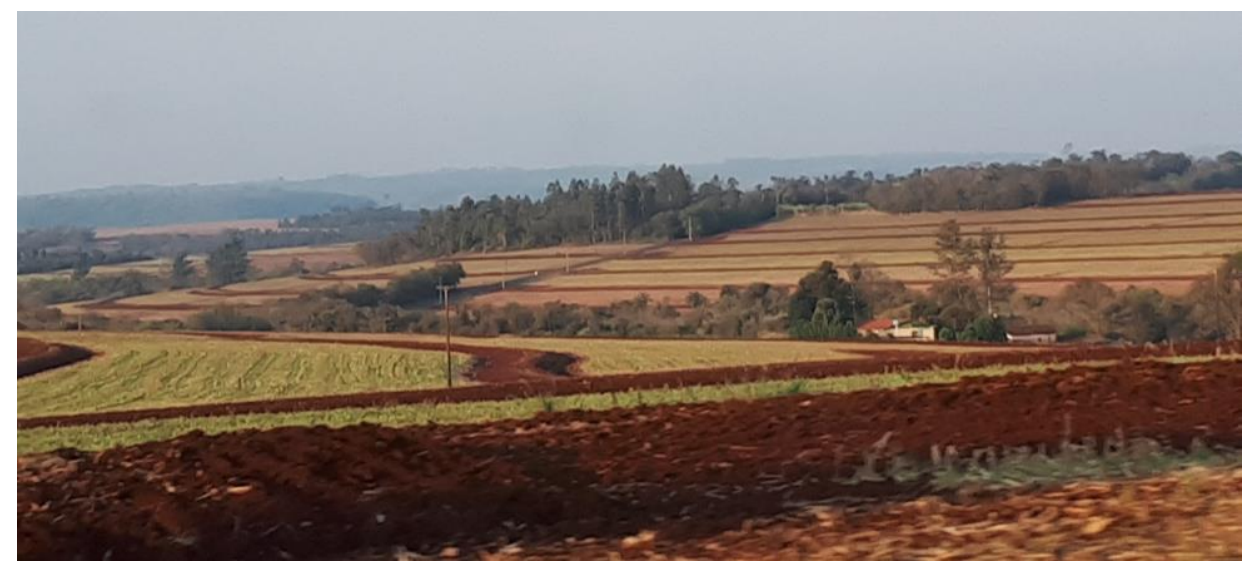

Nos setores onde foram identificadas as subclasses Vls, a e Vls,e, além de práticas conservasionistas irregulares, também se observam incompatibilidade de usos, considerando a realidade pedológica e topográfica da área. As áreas caracterizadas pelas subclasses VIs,a e VIs,e representam as terras com limitações severas, geralmente inadequadas para cultivos e com uso limitado para pastagens, florestas cultivadas ou nativas, para refúgio de flora e fauna silvestre.

O setor delimitado pela subclasse VIs,a contempla os solos com presença de hidromorfia, do tipo Gleissolo Háplico, comumente localizados em setores de fundos de vale e cabeceiras de drenagem e

\begin{tabular}{llllll}
\hline Caminhos de Geografia & Uberlândia - MG & v. 19, n. 68 & Dez/2018 & p. 266-285 & Página 279
\end{tabular}


geralmente apresentam formas côncavas e/ou planas. Nesses setores, não ocorrem restrições em relação ao declive, pois os gradientes são inferiores a $3 \%$ de declividade. No entanto, em termos pedológicos e hídricos, a baixa espessura do solo e o excesso de umidade, associado ao caráter hidromórfico, constituem elementos de restrição à atividade agrícola. Dessa forma, segundo o sistema de capacidade de uso, são indicados para pastagem ou reflorestamentos adaptados as condições de solo úmido, sendo que a eventual implantação de obras de drenagem deve receber manutenções periódicas.

Os setores onde ocorrem a subclasse Vls,a, é ocupado tanto por vegetação nativa ou reflorestada, como por pastagem em associação com a piscicultura e mais pontualmente por culturas agrícolas. Os setores ocupados por vegetação estabelecem uma importante proteção natural para o solo e para as cabeceiras de drenagem e planícies alagadiças, evitanto a erosão e o assoreamento dos córregos e nascentes. A presença da mata reflorestada nos setores onde ocorrem os Gleissolos vem aumentando substancialmente nas últimas quatro décadas, devido as políticas e leis ambientais vigentes, ICMS ecológico e implantação dos projetos de conservação do solo e da água. A promoção dos projetos de reflorestamento das áreas de preservação permantente, tais como o Projeto Cultivando Água Boa, fomentado pela usina hidroelétrica de Itaipu, bem como o Programa Integrado de Conservação de Água e Solo e Programa de Gestão de Bacias desenvolvido pelos institutos estaduais, tem promovido um importante reflorestamento nas áreas de matas ciliares e nascentes. Segundo Bade et al. (2016), entre as décadas de 1980 e 2010, a área ocupada por vegetação na BP3, compreendia um total de $765,93 \mathrm{~km}^{2}(8,82 \%)$ em 1982 e passou para um total de $1308,70 \mathrm{~km}^{2}$ (15,06\%) em 2010.

As áreas delimitadas pela classe VIs,a quando ocupados por vegetação apresentam compatibilidades de uso. Em contrapartida também se verifica atividades voltadas à pastagem, piscicultura e agricultura em alguns setores. As áreas ocupadas por pastagem e piscicultura, quando utilizadas com controle adequado de pisoteio e manutenção periódica das obras de drenagem, pode ser caracterizada como área de máxima utilização, ou seja, o uso é compatível, porém com a necessidade de um controle rigoroso das técnicas de conservação. Nesses setores conforme apontam Magalhães e Cunha (2007), o uso intensivo, junto ao planejamento mínimo de atividade pecuária, associado à compactação do solo pelo pisoteio do gado, bem como a falta de manutenção ou a interdição dos açudes de criação de peixes, tem gerado a degradação dos setores de fundo de vale (Figura 10). Nesse mesmo contexto, ainda ocorrem áreas ocupadas por cultivos temporários de milho e de soja que evidenciam usos inadequados, caracterizados pelo sistema de capacitada como área sobre-utilizada.

Figura 10: Fundo de vale degradado, localizado em áreas de Gleissolos (subclasse VIs,a).

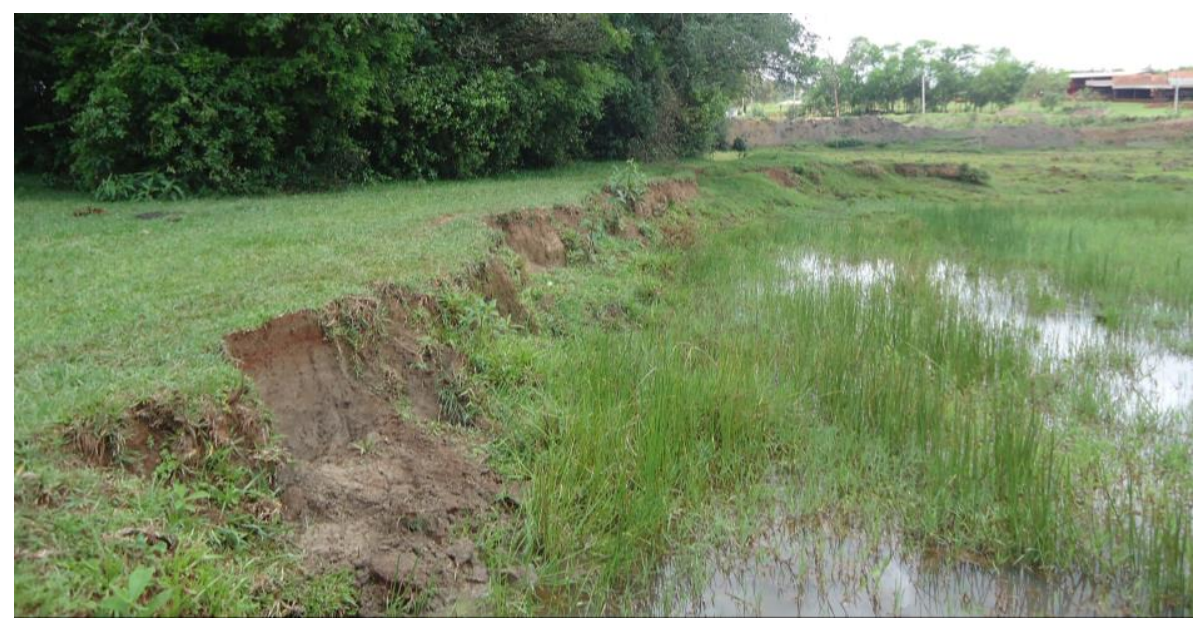

No que se refere a subclasse VIs,e, as restrições de uso agrícola encontram-se associadas à baixa profundidade dos solos do tipo Neossolo (Litólico e Regolítico) e ao relevo muito dissecado (declividades entre $20-30 \%$ ), composto por vertentes convexas e retilíneas, com frequentes rupturas

$\begin{array}{llllll}\text { Caminhos de Geografia } & \text { Uberlândia - MG } & \text { v. 19, n. 68 } & \text { Dez/2018 } & \text { p. 266-285 Página } 280\end{array}$


de declive, geralmente fortes e bem marcadas. Nesses setores, o risco de erosão é elevado devido à baixa permeabilidade e à alta declividade que favorecem o escoamento superficial. Dessa forma, são áreas indicadas para pastagens, com rigoroso controle de pastoreio, podendo ainda ser utilizadas para cultivos perenes, desde que contribuam para a proteção do solo.

$\mathrm{Na} \mathrm{BP}$, as áreas onde ocorrem a subclasse VIs,e normalmente apresentam-se recobertas por vegetação ou pastagem. As áreas mais dissecadas, geralmente são compostas por reservas legais, sendo que as de moderada dissecação onde as declividades são próximas a $20 \%$, ocorrem mais frequentemente 0 uso da pastagem, com atividade voltada a produção de gado de corte. Nesses setores, embora o uso seja adequado a realidade morfopedológica, verifica-se a necessidade de um maior planejamento em termos do uso pecuário. Em grande parte desses setores não são verificados sistemas de piquete e as curvas de nível apresentam distâncias muito amplas, considerando a elevada declividade. Dessa forma o escoamento superficial, atrelado a compactação do solo e ao relevo dissecado, juntamente com ao uso intensivo e sem planejamento adequado, tem favorecido o desenvolvimento de alguns sulcos que vem evoluindo para ravinas (Figura 11). Desse modo pode-se perceber que embora ocorra compatibilidade em termo de uso, também se evidencia a necessidade de maior atenção para as práticas de conservação do solo nesses setores.

Figura 11: Erosão em ravinas no primeiro plano e vegetação, pastagem e agricultura no segundo plano (subclasse Vls,e).

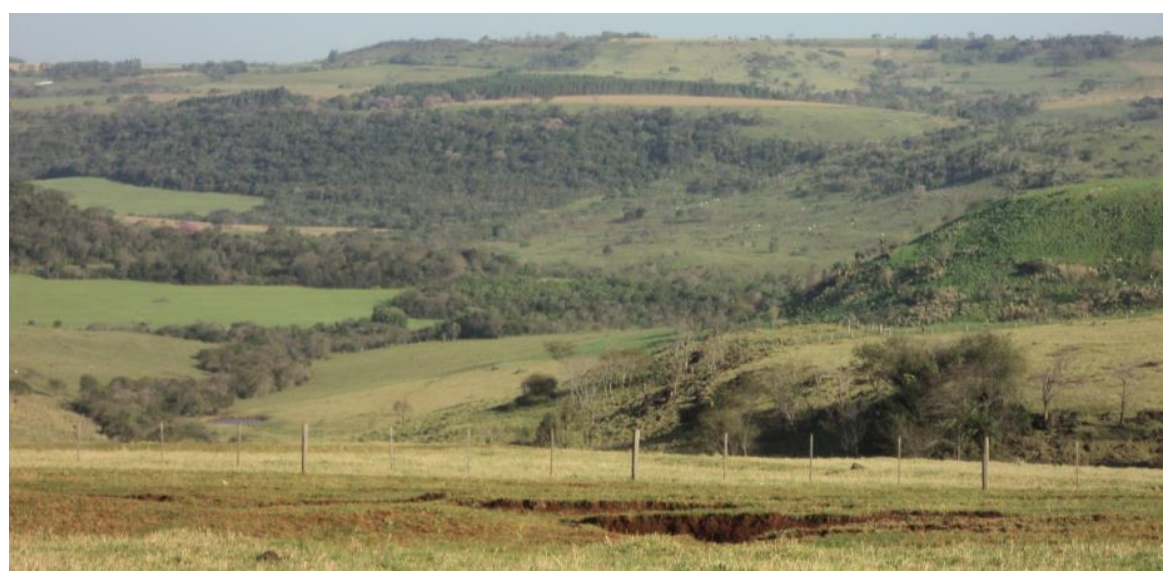

Em termos de distribuição espacial, verifica-se que a subclasse de capacidade VIs,a ocorre apenas no baixo setor localizado a Oeste, enquanto a subclasse VIs,e concentra-se particularmente na região central da bacia (Figura 7).

Em toda a extensão da BP3, a área de maior restrição ambiental é encontrada em uma estreita faixa no extremo Norte, onde se verifica a subclasse VIIls, a. As restrições ocorrem devido à presença dos Organossolos Háplicos, localizados à margem do Lago de Itaipu. Nesses setores, a baixa profundidade e permeabilidade do solo, associada à saturação de água e à tendência de inundação constante, justificam a restrição de uso de todos os tipos de atividades agrícolas e de pecuária. Desse modo, recomenda-se que essas áreas sejam destinadas ao abrigo e proteção da fauna e da flora silvestre e/ou apenas para ambientes de recreação protegidos, podendo ainda ser utilizados para armazenamento de água, conforme sugerem Lespch et al. (2015).

Os setores de maior restrição ambiental (subclasse VIIIs,a), quando situados as margens do lago de Itaipu encontram-se protegidos por mata cilar, devido a faixa de proteção obrigatória do reservatório de Itaipu e do rio Paraná. No entanto, também se verificam áreas sobre-utilizadas compostas por pequenas áreas de pastagens intercaladas por agricultura. Considerando a constante inundação nos períodos de maior precipitação e o hidromorfismo presente nos solos, propõe-se que todos setores compostos por Organossolos sejam destinados exclusivamente para áreas de preservação permanente.

$\begin{array}{llllll}\text { Caminhos de Geografia } & \text { Uberlândia - MG } & \text { v. 19, n. } 68 & \text { Dez/2018 } & \text { p. 266-285 } & \text { Página } 281\end{array}$


Ao comparar o uso atual das terras (Figura 6), com a carta de capacidade de uso (Figura 7), foi possível identificar e mapear as áreas que apresentam uso adequado a capacidade de uso, bem como as áreas que apresentam uso inadequado a capacidade de uso na BP3 - (Figura 12).

Figura 12: Mapa de compatibilidade do uso da terra na Bacia Hidrográfica do Paraná 3.

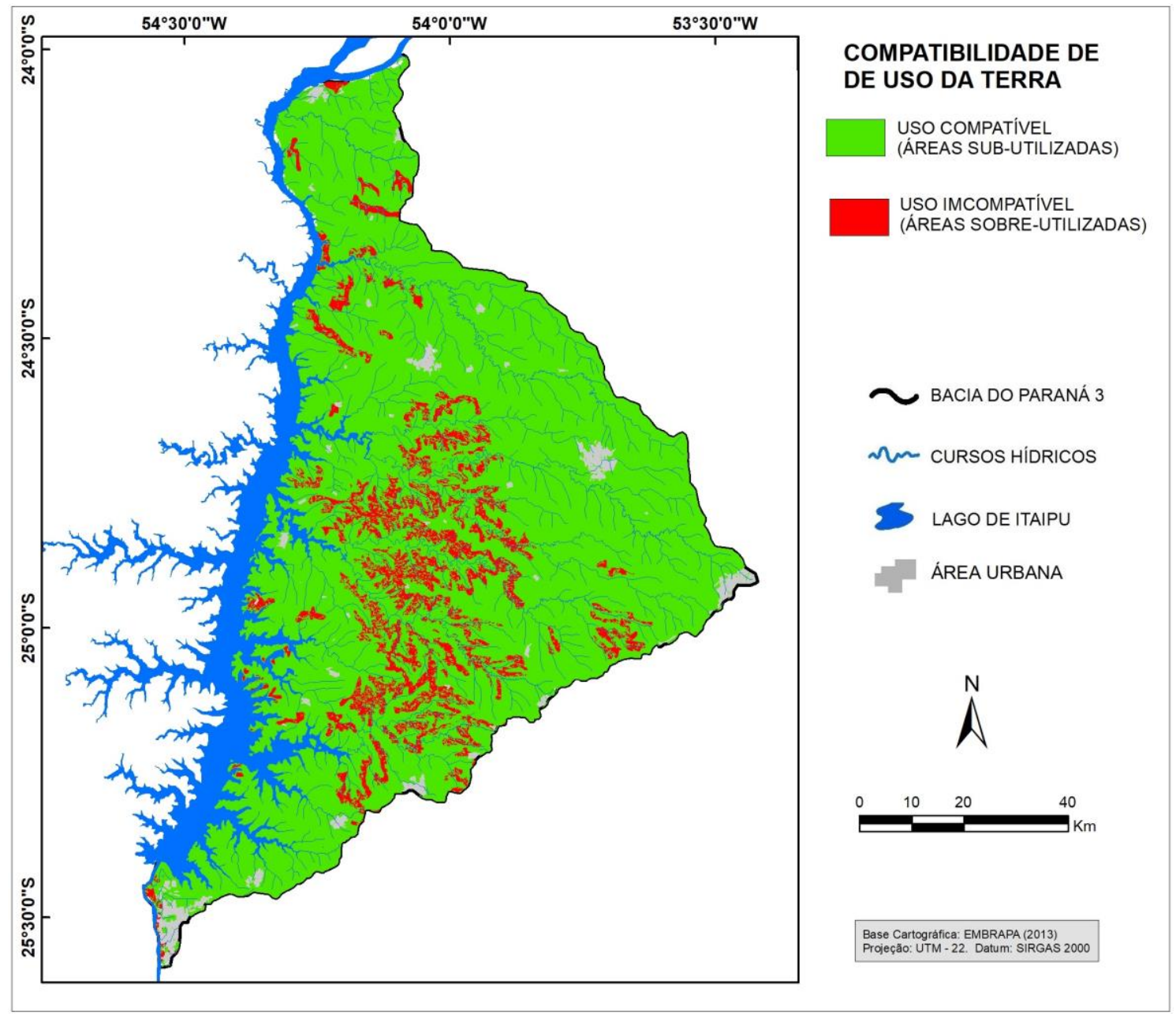

As áreas com uso atual compatível com as recomendações de capacidade de uso representam (83\%) do total da bacia e compõem princialmente as subclasses (II e III), que ocupam principalmente os setores onde ocorrem os Latossolos e Nitossolos, geralmente associados a cultivos agrícolas, com técnicas de conservação associadas ao platio direto e cultivo em nível. As áreas de uso compatível, também comportam uma maior diversidade de atividades agropecuárias e podem ser consideradas segundo o sistema de capacidade como área sub-utilizadas.

As áreas caracterizadas com uso incompatível com as recomendações de capacidade de uso representam (17\%) da bacia e ocorrem particularmente nas subclasses (VI e VIII), abrangendo principamente solos da odem dos Neossolos, Gleissolos e Organossolos. Nos setores onde ocorre a subclasse (VIs,e) o uso irracional encontra-se atrelado a cultivos agrícolas em áreas de alta dissecação e solos rasos (Neossolos), onde são recomendados o uso de pastagem e/ou reflorestamento. Nos setores onde ocorre a subclasse (Vls,a) o uso inadequado é composto por agricultura e pastagem sem controle de drenagem em ambientes de solos hidromóficos (Gleissolos). Realidade semelhante é encontrada na subclasse (VIIIs,a), onde se constatam áreas agrícolas e de pecuárias, onde seriam recomendadas apenas áreas de preservação permanente. As áreas

$\begin{array}{llllll}\text { Caminhos de Geografia } & \text { Uberlândia - MG } & \text { v. 19, n. 68 } & \text { Dez/2018 } & \text { p. 266-285 Página } 282\end{array}$


identificadas com o uso inadequado, podem ser caracterizadas com áreas sobre-utilizadas segundo o sistema de capacidade de uso, e por conseguinte, são também as áreas onde devem ocorrer necessariamente readequações ou mesmo extinção de determinadas atividades antrópicas rurais, considerando sobretudo, os limites físico-naturais e os riscos de degradação.

\section{CONSIDERAÇÕES FINAIS}

A organização e distribuição espacial da cobertura pedológica, associada a morfologia do relevo no contexto territorial da Bacia Hidrográfica do Paraná 3, são responsáveis por determinar diferentes níveis de capacidade de uso. Desse modo, a identificação, o mapeamento e a quatificação das subclasses de capacidade de uso, quando comparadas ao uso atual das terras, permite recomendar distintas práticas de conservação do solo, que contribuiem tanto para o planejamento e produtividade rural, quando para a conservação do dos solos das áreas ambientalmente mais frágeis.

As áreas mapeadas com as subclasses II e III representam os setores com maior potencialidade de uso agrícola e pecuário da bacia. As primeiras por apresentarem solos do tipo Latossolo Vermelho e declividades baixas, geralmente inferiores a $3 \%$, necessitam apenas de práticas simples de conservação. Nessas áreas o cultivo agrícola temporário e o sistema de platio direto empregado apresentam-se compatíveis com as recomendações de uso e manejo. Já ás áreas mapeadas com as subclasses III embora apresentem compatibilidade de uso, precisam urgentemente de maiores cuidados em relação às práticas conservacionistas, sobretudo nos setores de baixa vertente. Cabe destacar que esses setores compõem solos de textura argilosa e textura média e declividades levemente acentuadas e que vem apresentando indícios de degradação do solo em virtude da negligência em relação as práticas de terraceamento e rotatividade de culturas. Desse modo, a construção de novos terraceamento e recuperação dos já existentes, juntamente com o planejamento voltado para a rotatividade de culturas e descompactação do solo, considerando rigorasamente as especificações de declividade e textura do solo, podem contribuir com diminuição do escoamento superficial do solo. Essas práticas podem auxiliar na contenção de processos erosivos laminares e lineares e maior permanência de nutrientes nos horizontes superficiais, assegurando portantanto, a conservação do solo e consequentente o aumento de produtividade agrícola. Cabe ressaltar ainda, que ambos os setores (sublasses II e III), apresentam ainda pontecialidade para uma grande diversidade de culturas agrícolas e pecuárias, bem para a produção de fruticultura e horticultura, entre outras atividades já recomendados pelos órgãos de pesquisas regionais. A possibilidade de uma maior diversificação de produção tem sido recomendada por um conjunto de instituições visando a recomposição da qualidade ambiental do solo e da água, ou mesmo a ampliação de produtividade.

Em outro contexto apresentam-se as áreas que englobam as subclasses VI e VIII. Essas áreas além de apresentarem problemas associados às práticas de manejo, constituem setores de prioridade em relação a readequação do uso do solo. Em ambos os casos se verificam imcompatibiliade de uso. Nas áreas onde se observam as subclasse VIs,e, solos rasos (Neossolos) e a alta declividade (20$30 \%$ e $>30 \%$ ), a utilização intensiva da pastagem tem gerado a compactação e erosão dos solos, sendo que nas áreas onde ocorrem as subclasses VIs,a e VIII a fragilidade ambiental dos solos hidromórficos e orgânicos não tem sido respeitada, sendo muitas vezes utilizada pela piscicultura, pastagem ou mesmo agricultura sem o controle adequado de drenagem e sem respeitar os limites impostos pela legislação em setores marginais dos rios, cabeceiras de drenagem e nascentes. Desse modo, recomenda-se um melhor planejamento das atividades da pecuária, com práticas de controle a erosão, nas áreas onde se encontram os Neossolos, assim com maior fiscalização dos órgãos ambientais nos setores onde vem ocorrendo processos erosivos. Pode-se recomendar ainda a implantação de áreas de preservação onde ocorrem solos mais suscetíveis a inundação e ao assoreamento (Gleissolos e Organossolos) visando a recomposição de áreas de reserva legal no intiuito de proteger as nascentes e evitar o assoreamento dos rios. Nesses setores, também se verificam uma importante área ocupada por vegetação (nativa e reflorestada) e nas áreas de proteção das matas ciliares, nascentes e reserva legal, no entanto, constata-se que ainda existem áreas frágeis com a necessidade de preservação.

Nesse sentido, é importante destacar que a distribuição das áreas de uso compatíveis e incompatíveis se distribuem de forma diferenciada ao longo da bacia, fato que pode contribuir para o desenvolvimento de intervenções voltadas ao planejamento rural e ambiental, assim como para propostas de implantação de práticas conservacionistas de forma espacializada. 


\section{REFERÊNCIAS}

BADE, M. R.; ROCHA, A. S.; CUNHA, J. E.; NOBREGA, M. T. Análise temporal do uso e cobertura da terra das bacias hidrográficas do Paraná III (Brasil) e do Alto Paraná (Paraguai). In: VIII SIMPGEO SIMPÓSIO PARANAENSE DE PÓS-GRADUAÇÃO E PESQUISA EM GEOGRAFIA. Marechal Cândido Rondon: 2016

BATISTA. M. Estudo morfopedológico de uma topossequência de solos no Município de Terra Roxa-PR. 72f. 2018. Dissertação (Mestrado em Geografia) - Universidade Estadual do Oeste do Paraná, Marechal Cândido Rondon - PR, 2018.

BHERING, S. B.; SANTOS, H. G.; MANZATTO, C. V.; BOGNOLA, I.; FASOLO, P. J; CARVALHO, A. P.; POTTER, O.; AGLIO, M. L. D.; SILVA, J. S.; CHAFFIN, C. E.; CARVALHO JUNIOR, W. Mapa de solos do Estado do Paraná: escala 1:250.000. Rio de Janeiro: Embrapa Solos, 2008.

EMBRAPA - Empresa Brasileira de Pesquisa Agropecuária. Sistema Brasileiro de Classificação de Solos. 3를 Edição. Brasília: EMBRAPA, 2013.

EMBRAPA - Empresa Brasileira de Pesquisa Agropecuária. News. Erosão: prejuízos econômicos e ambientais no Paraná. 2018. Disponível em: <http://bit.ly/2wQ1Yuj>. Acesso em: 04/09/2018.

FLAUZINO, B. K.; MELLONI, E. G. P.; PONS, N. /A. D.; LIMA, O. Mapeamento de capacidade de uso da terra como contribuição ao planejamento de uso do solo em sub-bacia hidrográfica Piloto no sul de Minas Gerais. Geociências, São Paulo, v. 35, n. 2, p.277-287, 2016.

INPE - Instiuto Nacional de Pesquisas Espaciais. Catálogo de Imagens. Disponível em: <http://www.dgi.inpe.br/CDSR/>. Acesso em: 02 de setembro de 2015.

INPE - Instiuto Nacional de Pesquisas Espaciais. Banco de Dados Geomorfométricos do Brasil. Disponível em: <http://www.dsr.inpe.br/topodata/>. Acesso em: 20 de janeiro de 2016.

ITCG - Instituto de Terras Cartografia e Geologia do Paraná. Dados e Informações Geoespaciais Temáticas. 2013. Disponível em: <http://www.itcg.pr.gov.br/>. Acesso em: 23 de março de 2013

LEPSCH, I. F.; BELLINAZZI JR., R.; BERTOLINI, D.; ESPÍNDOLA, C. R. Manual para levantamento utilitário do meio físico e classificação de terras no sistema de capacidade de uso: $4^{\text {a }}$ aproximação. Campinas: SBCS, 1991.

LEPSCH, I. F.; ESPINDOLA, C. R.; VISCHI FILHO, J. O; HERNANI, L. C.; SIQUEIRA, D. S. Manual para levantamento utilitário e classificação de terras no sistema de capacidade de uso. Campinas: Sociedade Brasileira de Ciência do Solo, 2015.

MAGALHÃES, V. L.; CUNHA, J. E. O solo como base da sustentabilidade agrícola: estudo de caso no município de Marechal Cândido Rondon-PR. Ra'e ga, Curitiba. v. 12, p. 179-193, 2006.

MAGALHÃES, V. L.; CUNHA, J. E. Uso e degradação do solo no fundo de vale da sanga Creoula, distrito de Margarida, município de Marechal Cândido Rondon-PR. Geografia, Londrina, v. 16, p. 4961, 2007.

MELO, A. C.; GUERRA, H. O. Análise da capacidade de uso da terra utilizando à formula mínima obrigatória no assentamento Patativa do Assaré no município de Patos/PB. ACTA Geográfica, Boa Vista, v.7, n.14, p.55-75, 2013. https://doi.org/10.5654/actageo2013.0714.0004

MINEROPAR - Serviço Geológico do Paraná. Mapas Geológicos 1:250.000. 2015. Disponível em: <http://www.mineropar.pr.gov.br/>. Acesso em: 10 de janeiro 2015.

NANNI, M. R.; NEIRO, E. S.; NUNES, E. S.; COMUNELO, E.; DEMATTÊ, J. A. M. Estabelecimento da capacidade de uso das terras como subsídio para o zoneamento ecológico-econômico da área de proteção ambiental federal das llhas de Várzeas do Rio Paraná. Revista de Ciências AgroAmbientais, Alta Floresta, v.3, p.1-14, 2005.

ROCHA, A. S.; BADE, M. R.; NÓBREGA, M. T.; CUNHA, J. E. Mapeamento da fragilidade potencial e emergente na bacia hidrográfica do Paraná 3. Estudos Geográficos, Rio Claro v. 14, p. 43-59, 2016.

SANCHES, R. M. Sistemas de transformação e suas relações com a erosão hídrica em solos de textura média em Terra Roxa-PR. 89f. 2018. Dissertação (Mestrado em Geografia) Universidade Estadual do Oeste do Paraná, Marechal Cândido Rondon - PR, 2018. 
SANTOS, L. J. C.; OKA-FIORI, C.; CANALI N E, FIORI A P, SILVEIRA, C. T.; SILVA, J. M. F.; ROSS J. L. S.; Mapeamento Geomorfológico do Estado do Paraná. Revista Brasileira de Geomorfologia, v.7, n.2, p. 3-11, 2006. https://doi.org/10.20502/rbg.v7i2.74

SANTOS. P. G.; BERTOL, I.; CAMPOS, M. L.; NETO, S. L. R.; MAFRA, A. L. Classificação de terras segundo sua capacidade de uso e identificação de conflito de uso do solo em micro bacia hidrográfica. Revista de Ciências Agroveterinárias. Lages, v.11, n.2, p. 146-157, 2012.

SEAB - Secretaria da Agricultura e do Abastecimento do Paraná. Programa Integrado de Conservação de Solo e Água no Paraná. 2017. Disponível em <http://www.prosolo.pr.gov.br/modules/conteudo/conteudo.php?conteudo=3>. Acesso em: 05 de agosto de 2017.

SEMA - Secretaria de Estado do Meio Ambiente e Recursos Hídricos. Bacias Hidrográficas do Paraná. Curitiba. 2ª Edição. 2013.

SILVA, E. B. NOGUEIRA, R. E.; UBERTI, A. A. A. Avaliação da aptidão agrícola das terras como subsídio ao assentamento de famílias rurais, utilizando sistemas de informações geográficas. Revista Brasileira de Ciência de Solo. n.34, p. 1977-1990, 2010. https://doi.org/10.1590/S010006832010000600022

Recebido em: 18/12/2017

Aceito para publicação em: 30/10/2018 